\title{
ANALISIS PERTANGGUNGJAWABAN PIDANA PELAKU PENYALAHGUNAAN NARKOTIKA YANG DIBERIKAN REKOMENDASI REHABILITASI (Studi Putusan Nomor 67/ Pid.Sus/ 2017/ PN.Kbu)
}

\author{
Bambang Hartono ${ }^{1}$, I Ketut Seregig ${ }^{2}$, Andri Gustami ${ }^{3}$ \\ Program Magister Hukum Universitas Bandar Lampung \\ Jl. ZA Pagar Alam, Bandar Lampung. \\ Email: bambang.hartono@ubl.ac.id; iketutseregig@ubl.ac.id; andrigustamu@studentubl.ac.id
}

\begin{abstract}
Abstrak
Undang-Undang Nomor 35 Tahun 2009 tentang Narkotika adalah Undang-Undang yang direvisi dan dibuat untuk memberikan filter atau batasan bagi masyarakat agar yang termasuk jenis-jenis narkotika dan psikotropika, digunakan hanya untuk kepentingan medis/pengobatan dengan dosis tertentu yang sudah ditetapkan.
\end{abstract}

Permasalahan penulisan ini adalah Bagaimanakah proses pemberian rekomendasi rehabilitasi penyalahgunaan narkotika oleh Tim Asesment Terpadu. Bagaimanakah pertanggungjawaban pidana pelaku tindak pidanapenyalahgunaan narkotika Putusan Nomor 67/ Pid.Sus/2017/ PN. Kbu, Bagaimana upaya yang dilakukan oleh Satuan Narkoba Kepolisan Resor Lampung Utara dalam menanggulangi peredaran gelap narkoba di Wilayah Lampung Utara?

Metode penelitian yang digunakan yaitu yuridis normatif dan empiris, menggunakan data sekunder dan primer, yang diperoleh dari studi kepustakaan dan studi lapangan, dan analisis data dengan analisis yuridis kualitatif.

Hasil penelitian tesis ini yaitu Proses rekomendasi rehabilitasi penyalahgunaan narkotika oleh Tim Asesment Terpadu untuk pecandu narkotika yang tertangkap tangan dilakukan dengan cara menentukan pecandu narkotika tersebut murni/konsumen atau pecandu merangkap pengedar, adanya permohonan tertulis dari penyidik, Rekomendasi Tim Asesmen Terpadu berisi keterangan mengenai peran tersangka dan/atau terdakwa dalam tindak pidana, tingkat ketergantungan penyalahguna narkotika, rekomendasi kelanjutan proses hukumnya dan tempat serta lama waktu rehabilitasi. Pertanggungjawaban Pelaku Tindak Pidana Penyalahgunaan Narkotika pada Putusan Nomor 67/ Pid.Sus/2017/ PN. Kbu yaitu pidana penjara masing-masing selama 2 (dua) bulan dan menyatakan pidana tersebut dijalani terdakwa dalam bentuk rehabilitasi medis, Upaya yang dilakukan oleh Satuan Reserse Narkoba Kepolisan Resor Lampung Utara dalam menanggulangi peredaran gelap narkoba di Wilayah Lampung Utara dilakukan dengan dua cara yakni : Upaya Non Penal terdiri dari upaya preemtif dan preventif

Saran yang diberikan yaitu perlunya peningkatan peran serta masyarakat Kabupaten Lampung Utara untuk mendukung upaya penanggulangan dan pemberantasan peredaran gelap narkoba yang di lakukan oleh Polres Lampung Utara sehingga peredaran dan penyalahgunaan narkoba di wilayah Lampung Utara dapat diatasi dengan maksimal

Kata Kunci: Pertanggungjawaban pidana, Penyalahgunaan Narkotika, Rehabilitasi 


\section{A. Latar Belakang Masalah}

Penyalahgunaan narkotika saat ini menjadi perhatian banyak orang dan terus menerus dibicarakan dan dipublikasikan. Bahkan, masalah penyalahgunaan narkotika menjadi perhatian berbagai kalangan. Hampir semuanya mengingatkan sekaligus menginginkan agar masyarakat Indonesia untuk tidak sekali-kali mencoba dan mengkonsumsi narkotika. Fakta yang disaksikan hampir disetiap hari baik melalui media cetak maupun elektronik, ternyata peredaran narkotika telah merebak kemana-mana tanpa pandang usia, terutama di antara generasi penerus bangsa dalam pembangunan Negara di masa mendatang. Narkotika saat ini telah disalahgunakan untuk dikonsumsi, diedarkan, dan diperdagangkan tanpa izin dari pihak berwenang. Hal ini dilakukan oleh pihak-pihak yang tidak bertanggung jawab dengan tujuan memperoleh keuntungan ekonomi.

Penyalahgunaan narkotika pada saat ini telah masuk dalam keadaan yang membahayakan, karena pelaku penyalahgunaan narkotika atau mengkonsumsi narkotika tidak hanya menargetkan orang dewasa namun juga golongan anak-anak atau remaja. Jumlah pelaku penyalahgunaan narkotika yang masih tergolong anak terus bertambah pada tiap Tahunnya, yang membuktikan bahwa sasaran peredaran narkotika tidak memandang usia.

Penyalahgunaan narkotika berkaitan erat dengan peredaran gelap sebagai bagian dari dunia kejahatan internasional. Mafia perdagangan gelap memasok narkoba, agar orang memiliki ketergantungan, sehingga jumlah suplai meningkat. Terjalin hubungan antara pengedar/bandar dan korban. Korban sulit melepaskan diri dari mereka, bahkan tak jarang mereka terlibat peredaran gelap, karena meningkatnya kebutuhan narkotika. ${ }^{1}$

Di satu sisi narkotika diperlukan dan digunakan untuk pengobatan manusia, namun di sisi yang lain narkotika juga disalahgunakan, maka hal tersebut membahayakan bagi manusia. Penyalahgunaan oleh para pemakai ini menyebabkan tidak hanya berpengaruh pada kehidupan individu - individu, tetapi memiliki dampak yang meluas hingga

${ }^{1}$ Lydia Harlina Martono, Satya Joewana, Menangkal Narkoba dan Kekerasan, Jakarta,Balai Pustaka, 2008, hlm.43 berdampak pada kehidupan masyarakat, bangsa, dan Negara serta ketahanan nasional Indonesia. ${ }^{2}$

Eksistensi aparat penegak hukum dalam hal visi dan misi penegakan hukumnya, baik dari tingkat, penyelidikan, penyidikan, penuntutan sampai ke tingkat peradilan, seharusnya memiliki persepsi yang sama sesuai tuntutan hukum dan keadilan masyarakat. Tindakan operasional aparat penegak hukum di lapangan secara kuantitas menunjukkan peningkatan frekuensinya, tapi belum mampu menurunkan intensitas kejahatan tersebut. Oleh sebab itu, dalam hal penegakan hukum diharapkan para aparat penegak hukum dituntut profesionalitasnya di bidang hukum dengan ditunjang oleh etika profesi hukum.

Berdasarkan hal tersebut di atas, sistem penegakan hukum terhadap tindak pidana narkotika sangat ditentukan oleh faktor nilai-nilai, aturan-aturan, dan norma-norma hukum. Mekanisme peredaran dan pemasaran narkotika, sangat ekuivalen dengan keberadaan tempat-tempat hiburan malam serta pemasaran narkotika seiring beredar di tempattempat tersebut. Di sini, terdapat suatu paradigma antagonis, yaitu keberadaan tempat-tempat hiburan tersebut, di sisi lain memberikan lapangan kerja dan memberikan pendapatan daerah, serta menunjang pengembangan daerah metropolitan, tapi pada sisi lainnya, memberikan dampak terjadinya penyalahgunaan narkotika. Hal ini disebabkan oleh tidak patuhnya para pengelola tempat hiburan untuk ikut bertanggung jawab menyelamatkan generasi muda.

Pada saat ini terdapat pemidanaan yang berbeda terhadap pelaku penyalahgunaan narkotika, yaitu antara pidana penjara dan pidana rehabilitasi medis, sehingga terdapat disparitas atau perbedaan dalam pidana yang ditetapkan. Pidana penjara dikenal sebagai reaksi masyarakat sebagai adanya tindakan pidana yang dilakukan oleh seorang pelanggar hukum. Oleh karena itu pidana penjara juga disebut sebagai pidana hilang kemerdekaan. Seseorang dibuat tidak berdaya dan diasingkan secara sosial dari lingkungan semula. Majelis hakim dalam menjatuhkan pidana terhadap pengguna narkotika seharusnya mengedepankan keadilan dan berpegang teguh pada prinsip kesamaan warganegara di depan hukum, tetapi pada kenyataannya majelis hakim menjatuhkan

2 Hari Sasangka, Narkotika dan Psikotropika Dalam Hukum Pidana, Mandar Maju, Bandung, 2003, hlm. 5 
pidana yang berbeda terhadap dua pelaku tindak pidana penyalagunaan narkotika, antara penjara dan pidana rehabilitasi. Hal ini nampak pada Putusan Nomor 67/ Pid.Sus/ 2017/ PN. Kbu yang memvonis pelaku penyalahgunaan narkotika dengan rekomendasi rehabilitasi medis. Adapun kronologis perkaranya yaitu sebagai berikut:

Bahwa terdakwa I Deriansyah dan terdakwa II Handriansyah pada hari Rabu Tanggal 25 Januari 2017 sekira pukul 19.00 WIB atau setidaknya pada waktu lain yang masuk Tahun 2017 bertempat di Komplek Perumnas Sukajadi Desa Bumi Raya Kecamatan Abung Selatan Kabupaten Lampung Utara yang masuk dalam daerah hukum Pengadilan Negeri Kota Bumi, percobaan atau pemufakatan jahat tanpa hak atau melawan hukum, memiliki, menyimpan, menguasai, atau menyediakan narkotika golongan I bukan tanaman. Perbuatan para terdakwa dilakukan dengan caracara antara lain sebagai berikut:

Pada waktu dan tempat sebagaimana tersebut, bermula pada hari Rabu Tanggal 25 Januari 2017 sekira pukul 19.00 WIB saksi Ardiansyah, saksi Andi Rustam, Saksi Ego Fikri dan saksi Ahmad Ravit mendapat informasi dari masyarakat yang tidak mau menyebutkan identitasnya ada penyalahgunaan narkotika di Kali Pasir Desa Muara Jaya Kota Bumi Selatan setelah mendapatkan informasi tersebut para saksi dari Anggota Polres Lampung Utara atas perintah Kepala Satuan Narkotika Polres Lampung Utara langsung melakukan penggerebekan sebuah rumah di Kali Pasir Desa Muara Jaya Kota Bumi Selatan dan diamankan saksi Puja Elfa Randa dan saksi Randa ditemukan barang bukti narkotika jenis shabu yang terbungkus dengan plastik dan setelah ditanyakan barang tersebut adalah benar milik saksi Randa kemudian saksi Randa menceritakan bahwa 30 (tigas puluh) menit sebelum ditangkap terdakwa I telah membeli Narkotika seharga Rp. 200.000,- yang untuk digunakan bersama dengan terdakwa II.

Bahwa mendapat informasi tersebut para saksi dari anggota polisi tersebut langsung pengembangan dan langsung menuju rumah Terdakwa I di Perumnas Sukajadi Kecamatan Abung Selatan setelah sampai dirumah terdakwa I para saksi dari anggota Polres Lampung Utara langsung mengetuk pintu dan masuk kerumah terdakwa I dan menjelaskan bahwa para saksi adalah anggota anggota Polres Lampung Utara setelah itu langsung melakukan pemeriksaan dan penggeledahan rumah baik di ruang tamu, kamar tidur, dapur, dll ternyata di dalam kamar terdakwa I ditemukan alat hisap shabu (bong) yang terbuat dari aqua botol, 1 (satu) buah korek api gas, 1 (satu) buah plastik klip kecil bekas bungkus narkotika jenis shabu-shabu dan 5 (lima) buah cotton but.

Bahwa berita acara pemeriksaan laboratiris kriminalistik Laboratorium Forensik cabang Palembang Nomor Lab. 377/NNF/2017 dengan kesimpulan barang bukti berupa kristal-kristal putih dengan berat netto 0,005 gram pada tabel 1 dan urine pada tabel 2 milik terdakwa I bersama terdakwa II mengandung metafetamina. Perbuatan terdakwa tersebut diancam pidana dalam Pasal 112 ayat (1) jo Pasal 132 ayat (1) jo Pasal 127 UndangUndang Nomor 35 Tahun 2009 tentang Narkotika.

Berdasarkan putusan tersebut di atas Majelis Hakim dalam amar putusannya menghukum terdakwa dengan pidana penjara selama 2 bulan namun menyatakan bahwa pidana tersebut dijalani terdakwa dalam bentuk rehabilitasi medis. Bahwa berdasarkan hal tersebut diatas maka penulis tertarik untuk melihat dan mempelajari bagaimana proses pemberian rekomendasi rehabilitasi penyalahgunaan narkotika tesebut. Berdasarkan hal tersebut maka penulis akan menelitinya dalam bentuk tesis yang penulis beri judul " ANALISIS PERTANGGUNGJAWABAN PIDANA PELAKU PENYALAHGUNAAN NARKOTIKA YANG DIBERIKAN REKOMENDASI REHABILITASI(Studi Putusan Nomor 67/ Pid.Sus/ 2017/ PN.Kbu).

\section{B. PermasalahanPenelitian}

Berdasarkan uraian latar belakang yang telah dikemukakan diatas, dapat di kemukakan permasalahan sebagai berikut:

a. Bagaimanakah proses pemberian rekomendasi rehabilitasi penyalahgunaan narkotika oleh Tim Assessment Terpadu?

b. Bagaimanakah pertanggungjawaban pidana pelaku tindak pidanapenyalahgunaan narkotika Putusan Nomor 67/ Pid.Sus/2017/ PN. Kbu?

c. Bagaimana upaya yang dilakukan oleh Satuan Reserse Narkoba Kepolisan Resor Lampung Utara dalam menanggulangi peredaran gelap narkoba di Wilayah Lampung Utara?

\section{Metode Penelitian}

Penelitian hukum adalah suatu proses untuk menemukan aturan-aturan hukum, prinsip-prinsip hukum maupun doktrin-doktrin hukum guna 
menjawab isu hukum yang dihadapi. ${ }^{3}$ Sedangkan Metode Penelitian hukum merupakan ilmu tentang caramelakukan penelitian hukum dengan teratur (sistematis). ${ }^{4}$ Dalam melakukan kegiatan penelitian, peneliti melakukan kegiatan yang terdiri langkah-langkah sebagai berikut :

\section{Pendekatan Masalah}

Permasalahan yang terdapat dalam penelitian proposal tesis ini, peneliti melakukan dua pendekatan yaitu melaluipendekatan yuridis normatif dan pendekatan empiris guna untuk mendapatkan suatu hasil penelitian yang benar dan objektif sebagai berikut.

a. Pendekatan Yuridis Normatif

Pendekatan yuridis normatif yaitu pendekatan dengan cara menelaah kaedahkaedah, normanorma, aturan-aturan, yang berhubungan dengan masalah yang akan diteliti. Pendekatan tersebut dimaksud untuk mengumpulkan berbagai macam peraturan perundang-undangan, teori-teori dan literaturliteratur yang erat hubungannya dengan masalah yang akan diteliti yaitu mengenai masalah pertanggung jawaban pidana pelaku tindak pidana penyalahgunaan narkotika yang di berikan rekomendasi rehabilitasi.

b. Pendekatan Empiris

Pendekatan empiris dilakukan dengan cara meneliti dan mengumpulkan data primer yang diperoleh secara langsung melalui penelitian terhadap objek penelitian dengan cara wawancara dengan responder atau narasumber yang berhubungan dengan permasalahan yang dibahas mengenai pertanggung jawaban pidana pelaku tindak pidana penyalahgunaan narkotika yang di berikan rekomendasi rehabilitasi.

\section{Sumber dan Jenis Data}

Dalam melakukan penelitian, diperlukan keterangan-keterangan yang terkait dengan permasalahan yang berupa data. Adapun data yang diperlukan adalah sebagai berikut

a. Data Sekunder

Data sekunder adalah data yang digunakan dalam menjawab permasalahan pada penelitian ini melalui studi kepustakaan (library research) dengan cara membaca, mengutip, mempelajari dan menelaah

3 Peter Mahmud Marzuki, Penelilian Hukum, Prenada Media Group, Jakarta, 2005, hlm. 35

4 Abdulkadir Muhammad, Hukum dan Penelitian Hukum, PT. Citra Aditya Bakti, Bandung, 2004, hlm. 57 literatur-literatur atau bahan-bahan yang ada serta peraturan perundang-undangan yang berkaitan dengan permasalahan yang ada.

1) Bahan Hukum Sekunder

Bahan hukum sekunder adalah bahan hukum yang memberikan penjelasan mengenai bahan hukum primer seperti buku-buku literatur dan karya ilmiah yang berkaitan dengan permasalahan penelitian.

2) Bahan Hukum Tertier

Meliputi bahan hukum yang memberikan petunjuk dan penjelasan terhadap bahan hukum primer dan sekunder, berupa basil-basil penelitian terdahulu, buletin ilmiah, majalah, surat kabar, ensiklopedia, kamus Bahasa Indonesia dan kamus Bahasa Inggris serta pemanfaatan sumber dari internet dan sumber-sumber bacaan lainnya.

b. Data Primer

Data primer adalah data yang diperoleh secara langsung hasil penelitian di lapangan pada objek penelitian yang dilakukan di Pengadilan Negeri Kota Bumi, Kejaksaan Negeri Lampung Utara, Polres Lampung Utara, BNNP.

\section{Prosedur Pengumpulan dan Pengolahan Data}

\section{a. Prosedur Pengumpulan Data}

Untuk melengkapi data guna pengujian penelitian ini, digunakan prosedur pengumpulan data yang terdiri dari :

1) Studi Kepustakaan (Library Research)

Studi kepustakaan (library research) merupakan suatu upaya dalam mengumpulkan data sekunder yang dilakukan dengan cara cara membaca, mempelajari, mengutip dan menelaah literatur-literatur maupun peraturan perundang-undangan, serta bahan hukum lainnya yang menunjang dan berhubungan dengan permasalahan yang akan dibahas.

2) Studi Lapangan (Field Research)

Studi lapangan (Field Research) merupakan upaya dalam mengumpulkan data primer yang dilakukan dengan cara sebagai berikut

\section{b. Prosedur Pengolahan Data}

Setelah data terkumpul, selanjutnya adalah pengolahan data, yaitu kegiatan merapikan dan menganalisa data tersebut, kegiatan ini meliputi kegiatan seleksi data dengan cara memeriksa data 
yang diperoleh melalui kelengkapannya. Kegiatan pengolahan data ini dapat dilakukan melalui prosedur sebagai berikut:

1) Editing data, yaitu memeriksa atau meneliti data yang keliru, menambah serta melengkapi data yang kurang lengkap.

2) Klasifikasi data, yaitu penggolongan atau pengelompokan data menurut pokok bahasan yang telah ditentukan.

3) Sistematisasi data, yaitu penempatan data pada tiap pokok bahasan secara sistematis hingga memudahkan interpretasi data.

\section{Analisis Data}

Analisis data merupakan usaha untuk menemukan jawaban atas pertanyaan mengenai perihal di dalam rumusan masalah serta hal-hal yang diperoleh dari suatu penelitian pendahuluan. Dalam proses analisis data ini, rangkaian data yang telah tersusun secara sistematis menurut klasifikasinya kemudian diuraikan dan dianalisis secara deskriptif.

\section{F. Sistematika Penulisan}

Dalam upaya memudahkan pemahaman dari penelitian ini, maka peneliti membagi sistematika penulisan ke dalam V (lima) bab secara berurutan dan saling berhubungan yaitu sebagai berikut :

Bab 1. Pendahuluan, Bab ini merupakan bab pendahuluan yang berisikan uraian dari latar belakang masalah, permasalahan dan ruang lingkup penelitian, tujuan dan kegunaan penelitian, kerangka pemikiran, metode penelitian serta sistematika penulisan.

Bab II. Konsepsi Tindak Pidana Narkotika dan Rehabilitasi, Bab ini berisikan tentang teori-teori yang menjadi landasan teoritis dari permasalahan penelitian mengenai konsep pemidanaan antara lain berisi tentang pengertian pidana, pengertian dan jenis-jenis tindak pidana, pengertian pertanggung jawaban pidana, pengertian narkotika, dasar hukum tindak pidana narkotika, pengertian rehabilitasi, teori penegakan hukum pidana, teori pertimbangan Hakim, teori kebijakan kriminal.

Bab III. Tugas Pokok dan Fungsi Satuan Reserse Narkoba Polres Lampung Utara, Bab ini berisikan tugas pokok dan fungsi Satuan Reserse Narkoba Polres Lampung Utara, struktur organisasi pada Satuan Reserse Narkoba Polres Lampung Utara.
Bab IV. Analisis Pertanggungjawaban Pidana Pelaku Penyalahgunaan Narkotika Yang Diberikan Rekomendasi Rehabilitasi(Studi Putusan Nomor 67/ Pid.Sus/ 2017/ Pn.Kbu) Bab ini memuat pembahasan mengenai permasalahan tentang proses rekomendasi rehabilitasi penyalahgunaan narkotika oleh Tim Assessment Terpadu, pertanggungjawaban pelaku tindak pidanapenyalahgunaan narkotika Putusan Nomor 67/ Pid.Sus/2017/ PN. Kbu serta upaya yang dilakukan oleh Satuan Reserse Narkoba Kepolisan Resor Lampung Utara dalam menanggulangi peredaran gelap narkoba di Wilayah Lampung Utara.

Bab V. Penutup, Bab ini berisi kesimpulan terhadap jawaban permasalahan dari hasil penelitian yang didapat serta pemberian saran berdasarkan kesimpulan yang telah diambil demi perbaikan di masa yang akan dating.

\section{Pembahasan}

\section{Proses Rekomendasi Rehabilitasi Penyalahgunaan Narkotika Oleh Tim Assessment Terpadu}

Menurut Abdul Haris selaku Tim Assesment Terpadu BNNP Lampung mengatakan bahwa narkotika merupakan obat atau bahan yang bermanfaat di bidang pengobatan, pelayanan kesehatan dan pengembangan ilmu pengetahuan, namun di sisi lain dapat menimbulkan ketergantungan yang sangat merugikan apabila dipergunakan tanpa adanya pengendalian, pengawasan yang ketat dan seksama. Dalam dunia medis narkotika sangat diperlukan karena keampuhannya menghilangkan rasa nyeri.Narkotika merupakan bagian dari narkoba yaitu segolongan obat, bahan atau zat yang jika masuk ke dalam tubuh berpengaruh terutama pada fungsi otak (susunan syaraf pusat) dan sering menimbulkan ketergantungan. Terjadi perubahan dalam kesadaran, pikiran, perasaan, dan perilaku pemakainya.

Selanjutnya Menurut Agus Priambodo selaku Tim Hukum Assessment Terpadu mengatakan bahwa sesuai Pasal 54 Undang-undang Nomor 35 Tahun 2009 tentang Narkotika dinyatakan bahwa pecandu narkotika dan korban penyalahgunaan Narkotika wajib menjalani rehabilitasi medis dan rehabilitasi sosial. Rehabilitasi terhadap pecandu Narkotika adalah suatu proses pengobatan untuk membebaskan pecandu dari ketergantungan, dan masa menjalani rehabilitasi tersebut diperhitungkan sebagai masa menjalani hukuman. 
Rehabilitasi terhadap pecandu Narkotika juga merupakan suatu bentuk perlindungan sosial yang mengintegrasikan pecandu Narkotika ke dalam tertib sosial agar dia tidak lagi melakukan penyalahgunaan Narkotika.

Abdul Haris selaku Tim Assesment Terpadu BNNP Lampung mengatakan bahwa berdasarkan Undang-undang Nomor 35 Tahun 2009 tentang Narkotika terdapat setidaknya dua jenis rehabilitasi, yaitu rehabilitasi medis dan rehabilitasi sosial. Pasal 1 butir 16 Undang-undang Nomor 35 Tahun 2009 menyatakan bahwa rehabilitasi medis adalah suatu proses kegiatan pengobatan secara terpadu untuk membebaskan pecandu dari ketergantungan Narkotika. Kemudian Pasal 1 butir 17 Undang-undang Nomor 35 Tahun 2009 menyatakan bahwa rehabilitasi sosial adalah suatu proses kegiatan pemulihan secara terpadu, baik fisik, mental, maupun sosial, agar bekas pecandu narkotika dapatkembali melaksanakan fungsi sosial dalam kehidupan masyarakat.

Menurut M. Faisal Zhuhry selaku Hakim pada Pengadilan Negeri Kotabumi mengatakan Rehabilitasi bagi penyalahguna atau pecandu narkotika merupakan perintah dan amanat Pasal 54 Undang-undang Nomor 35 Tahun 2009 tentang Narkotikan yang diamanatkan bahwa pecandu narkotika wajib mendapatkanrehabilitasi medis dan rehabilitasi sosial. Amanah atau perintahtersebut harus dijalankan dengan benar, Undang-undang Narkotikamerupakan peraturan khusus yang mengkesampingkan KUHP, disisilain dengan kebijakan rehabilitasi tersebut juga merupakan strategiuntuk mengurangi dampak penyalahgunaan narkotika.

Menurut Aiptu Soenanto selaku Tim Hukum Assessment Terpadu bahwa pelaksaan Rehabilitasi terhadap Pecandu, Penyalahguna dan Korban Narkotika berdasarkan Rekomendasi Tim Asesmen Terpadu di Wilayah Hukum Badan Narkotika Nasional Provinsi Lampung dalam Praktek Peradilan Berdasarkan Pasal 127 Jo Pasal 54 Undang-Undang Republik Indonesia Nomor 35 Tahun 2009 Tentang Narkotika jelas telah menguraikan tentang adanya kewajiban rehabilitasi terhadap pecandu, penyalah guna dan korban narkotika. Adapun ketentuan rehabilitasi tersebut harus memiliki klasifikasi sesuai Surat Edaran Mahkamah Agung Nomor 4 Tahun 2010 tentang Penempatan Penyalahgunaan, korban penyalahgunaan dan pecandu narkotika ke dalam lembaga rehabilitasi medis dan rehabilitasi sosial yang diantaranya yaitu:

1. Pada saat ditangkap oleh penyidik Polisi dan Penyidik Badan Narkotika Nasional dalam kondisi tertangkap tangan.

2. Pada saat tertangkap tangan ditemukan barang bukti pemakaian 1 (satu) hari dengan perincian antara lain :

a. Kelompok Metamphetamine (shabu) : 1 gram

b. Kelompok MDMA (ekstasi) : 2,4 gram $=8$ butir

c. Kelompok Heroin : 1,8 gram

d. Kelompok Kokain : 1,8 gram

e. Kelompok Ganja : 5 gram

f. Daun Koka : 5 gram

g. Meskalin : 5 gram

h. Kelompok Psilosybin : 3 gram

i. Kelompok LSD (d-lysergic acid diethylamide) : 2 gram

j. Kelompok PCP (phencyclidine) : 3 gram

k. Kelompok Fentanil: 1 gram.

1. Kelompok Metadon: 0,5 gram

m. Kelompok Morfin: 1,8 gram

n. Kelompok Petidin: 0,96 gram

o. Kelompok Kodein: 72 gram

p. Kelompok Bufrenorfin: $32 \mathrm{mg}$

3. Surat Uji laboratorium Positif menggunakan narkotika berdasarkan permintaan penyidik.

4. perlu surat keterangan dari dokter jiwa/psikiater pemerintah yang ditunjuk oleh Hakim

5. tidak terdapat bukti bahwa yang bersangkutan terlibat dalam peredaran gelap narkotika.

Selanjutnya Aiptu Soenanto menjelaskan pecandu Narkotika dan Korban Penyalahgunaan Narkotika yang tertangkap tangan baik tanpa barang bukti dan terdapat barang bukti dengan jumlah tertentu maka terhadapnya dapat ditempatkan pada lembaga rehabilitas dengan panduan Berita Acara Pemeriksaan Laboratorium, Berita Acara Pemeriksaan oleh Penyidik dan dilengkapi dengan Surat Hasil Rekomendasi Tim Asesmen Terpadu yang sebelumnya telah diajukan oleh Penyidik ke Badan Narkotika Nasional. Proses selanjutnya adalah Pecandu Narkotika dan Korban Penyalahgunaan Narkotika yang tanpa hak dan melawan hukum sebagai Tersangka dan/atau Terdakwa dalam penyalahgunaan Narkotika yang sedang menjalani proses penyidikan, penuntutan, dan persidangan dipengadilan diberikan pengobatan, perawatan dan pemulihan dalam lembaga rehabilitasi.

Menurut Iptu Hartadi selaku Penyidik Sat Res Narkoba Polres Lampung Utara bahwa Penempatan tersangka pecandu narkotika di lembaga rehabilitasi merupakan inisiatif dari penyidik, jika tersangka diindikasi selama pemeriksaan hanya pecandu narkotika. Tersangka 
juga dapat melakukan permohonan untuk melakukan rehabilitasi, namun hal ini merupakan kewenangan dari penyidik untuk menyetujui atau tidak. Berdasarkan fakta empiris dilapangan jika pecandu terlibat dalam peredaran penyidik tidak akan memberikan rekomendasi rehabilitasi. Hal ini dilakukan untuk mengantisipasi pelaku mengedarkan dan memperluas pemasaran narkotika di tempat rehabilitasi. Mengingat di tempat rehabilitasi banyak dihuni oleh pacandu, yang akan dengan mudah terpengaruh dan akan merusak jalannya masa rehabilitasi yang bertujuan untuk memulihkan pecandu.Selanjutnya bahwa untuk merehabilitasi pecandu narkotika, diperlukan analisa dan pemeriksaan yang mendalam terhadap kasus penyalahgunaan narkotika. Berdasarkan bukti dan fakta dilapangan, juga dipengarugi oleh keyakinan penyidik bahwa pecandu memang hanya konsumen bukan pengedar, sehingga apabila benar bahwa yang tertangkap hanyalah pecandu narkotika, "maka tindakan penyidik akan mengajukan surat permohonan kepada tim assessment supaya dilakukan pemeriksaan dan segera direhabilitasi berdasarkan rekomendasi dari tim assessment terpadu"

Menurut Agus Priambodo selaku Tim Hukum Assessment Terpadu bahwa Proses rekomendasi rehabilitasi penyalahgunaan narkotika oleh Tim Assessment Terpadu untuk pecandu narkotika yang tertangkap tangan dilakukan dengan cara yaitu:

a. menentukan pecandu narkotika tersebut murni/konsumen atau pecandu merangkap pengedar sesuai dengan bukti-bukti dari proses penyidikan.

b. Tindakan selanjutnya adalah melakukan proses assessment oleh tim assessment terpadu. Tim Assesment Terpadu dibentuk berdasarkan kesepakatan mengenai pembentukan Peraturan Bersama. tim assessment terpadu bertempat dibawah lembaga BNN/Propinsi. Tim assessment dalam menjalankan tugasnya terbagi menjadi 2 tim, yaitu :

1) Tim hukum, yaitu pemeriksaan dari unsur Kepolisian, BNN, Kejaksaan dan Kemenkumham.

2) Tim medis, yaitu pemeriksaan dari dokter dan psikolog.

Adapun tugas pokok dari tim assessment terpadu, tim hukum melakukan analisis pengembangan jaringan dalam kaitanya peredaran gelap narkotika dan berkoordinasi dengan pihak penyidik yang menanganani kasus tersebut. Selanjutnya tim medis melakukan pemeriksaan dari segi kesehatan dan kejiwaan pecandu, sehingga menjadi dasar rekomendasi langkah rencana terapi dan rehabilitasi. Tim Assessment Terpadu juga mempunyai kewenangan yang mencakup, permintaan oleh penyidik untuk mendalami kasus dan analisis peran seorang yang ditangkap dan tertangkap oleh penyidik, guna menentukan sebagai pecandu narkotika atau pengedar narkotika.

c. Tim Asesmen Terpadu melakukan asesmen berdasarkan permohonan tertulis dari penyidik. Penyidik mengajukan permohonan paling lama 1x24 jam setelah penangkapan, dengan tembusan kepada Kepala BNNP Provinsi sesuai dengan tempat kejadian perkara.

d. Tim Asesmen Terpadu melakukan asesmen maksimal 2x 24 jam, selanjutnya hasil asesmen dari tim dokter dan tim hukum disimpulkan paling lama 3 hari ketiga.

e. Hasil Asesmen dari masing-masing tim asesmen dibahas pada pertemuan pembahasan kasus (case conference) pada hari keempat untuk ditetapkan sebagai rekomendasi Tim Asesmen Terpadu.

f. Rekomendasi Tim Asesmen Terpadu berisi keterangan mengenai peran tersangka dan/atau terdakwa dalam tindak pidana, tingkat ketergantungan penyalahguna narkotika, rekomendasi kelanjutan proses hukumnya dan tempat serta lama waktu rehabilitasi.

g. Rekomendasi Tim Assesmen terpadu di ditandatangani oleh ketua Tim Asesmen Terpadu. Dalam kepentingan peradilan hasil rekomendasi Tim Asesmen Terpadu dilampirkan dalam berkas perkara tersangka harus asli bukan dalam bentuk foto copy. Rekomendasi inilah yang menjadi dasar pertimbangan seorang hakim untuk menetapkan apakah tersangka terbukti dan dapat dibuktikan sebagai korban penyalah guna atau terbukti sebagai pelaku tindak pidana Narkotika atau Prekusor Narkotika.

Berdasarkan teori Volkgeist yang dikemukakan oleh Friedrich Carl von Savigny bahwa hukum tumbuh secara alamiah dalam pergaulan masyarakat yang mana hukum selalu berubah seiring perubahan sosial. Dengan pernyataan Savigny tersebut maka dapat diketahui bahwa pelaksanaan rehabilitasi bagi pecandu narkotika saat ini telah diatur di dalam Pasal 127 Jo Pasal 54 Undang-Undang Republik Indonesia Nomor 35 Tahun 2009 Tentang Narkotika yang mana Undang-Undang terdahulu tidak mengaturnya, hal ini sesuai dengan teori volkgeist yakni hukum itu 
tumbuh dan berkembang bersama-sama dengan masyarakat. berdasarkan teori tersebut maka Proses rekomendasi rehabilitasi penyalahgunaan narkotika oleh Tim Assessment Terpadu untuk pecandu narkotika yang tertangkap tangan dilakukan dengan cara yaitu:

a. Menentukan pecandu narkotika tersebut murni/konsumen atau pecandu merangkap pengedar sesuai dengan bukti-bukti dari proses penyidikan.

b. Tim Asesmen Terpadu melakukan asesmen berdasarkan permohonan tertulis dari penyidik.

c. Penyidik mengajukan permohonan paling lama 1x24 jam setelah penangkapan, dengan tembusan kepada Kepala BNNP Provinsi sesuai dengan tempat kejadian perkara.

d. Tim Asesmen Terpadu melakukan asesmen maksimal 2x 24 jam, selanjutnya hasil asesmen dari tim dokter dan tim hukum disimpulkan paling lama 3 hari ketiga.

e. Hasil Asesmen dari masing-masing tim asesmen dibahas pada pertemuan pembahasan kasus (case conference) pada hari keempat untuk ditetapkan sebagai rekomendasi Tim Asesmen Terpadu.

f. Rekomendasi Tim Asesmen Terpadu berisi keterangan mengenai peran tersangka dan/atau terdakwa dalam tindak pidana, tingkat ketergantungan penyalahguna narkotika, rekomendasi kelanjutan proses hukumnya dan tempat serta lama waktu rehabilitasi.

g. Rekomendasi Tim Assesmen terpadu di ditandatangani oleh ketua Tim Asesmen Terpadu.

\section{Pertanggungjawaban Pelaku Tindak Pidana Penyalahgunaan Narkotika Putusan Nomor 67/ Pid.Sus/2017/ PN. Kbu}

Menurut M. Faisal Zhuhry selaku Hakim pada Pengadilan Negeri Kotabumi bahwa Majelis Hakim dalam perkara tersebut memiliki beberapa pertimbangan - pertimbangan hukum dalam memutus perkara tersebut. Adapun pertimbangannya di dasarkan dari alat-alat bukti yang telah diungkap dipersidangan diantaranya yaitu:

\section{Adanya Keterangan Saksi}

bahwa dalam perkara Putusan Nomor 67/ Pid.Sus/ 2017/ PN. Kbu, Jaksa Penuntut Umum telah mengadirkan beberapa saksi yang menyatakan bahwa memang terdakwalah yang melakukan tindak pidana penyalahgunaan narkotika tersebut dan keterangan beberapa saksi tersebut saling bersesuaian antara yang satu dengan yang lainnya.

\section{Adanya Keterangan Ahli}

bahwa Jaksa Penuntut Umum juga menghadirkan Keterangan Ahli yakni Dr. Novan Harun yang menerangkan bahwa ahli merupakan dokter pertama pada seksi penguatan Lembaga rebhabilitasi didang rehabilitasi BNN Provinsi Lampung, bahwa terkait perkara yang dimaksud, menurut ahli para terdakwa memenuhi kriteria diagnosis Napza situasional user stimulantia (shabu) kemudian para terdakwa membenarkan keterangan tersebut dan tidak keberatan.

\section{Adanya bukti surat}

bahwa bukti surat yang di hadirkan jaksa penuntut umum yaitu berita acara pemeriksaan laboratiris kriminalistik Laboratorium Forensik cabang Palembang Nomor Lab. 377/NNF/2017 dengan kesimpulan barang bukti berupa kristal-kristal putih dengan berat netto 0,005 gram pada tabel 1 dan urine pada tabel 2 milik terdakwa I bersama terdakwa II mengandung metafetamina. Kemudian surat keputusan Kepala BNN Provinsi Lampung Nomor KEP/42/I/Ka/Rh.00/2017 /BNNP-LPG Tanggal 3 Januari 2017 Tentang Penetapan Tim Assessment terpadu tingkat Provinsi Lampung Tahun 2017 dan berdasarkan berita acara rapat pembahasan Kasus Nomor BA/03/II/TAT/2017/BNNP Tanggal 08 Februari 2017.

4. Menimbang surat dakwaaan Jaksa Penuntut Umum

Menimbang bahwa para terdakwa telah didakwa oleh penuntut Umum dengan dakwaan alternatif yaitu pertama primair melanggar Pasal 112 ayat (1) jo Pasal 132 Undang-Undang Nomor 35 Tahun 2009 tentang Narkotika Subsidair yang melanggar Pasal 112 ayat (1) Undang-Undang Nomor 35 Tahun 2009 tentang Narkotika atau kedua yang melanggar Pasal 127 ayat (1) huruf a UndangUndang Nomor 35 Tahun 2009 tentang Narkotika, yang kemudian berdasarkan fakta-fakta hukum yang terungkap dipersidangan Majelis Hakim berpendapat bahwa dakwaan yang tepat dikenakan oleh para terdakwa adalah dakwaan kedua.

5. Terpenuhinya Unsur - Unsur dalam Pasal 127 ayat (1) huruf a Undang-Undang Nomor 35 Tahun 2009 tentang Narkotika

Bahwa berdasarkan bukti-bukti yang diungkap di persidangan maka didapat fakta-fakta hukum tentang unsur dalam Pasal 127 ayat (1) huruf a Undang-Undang Nomor 35 Tahun 2009 tentang Narkotika yaitu:

a.. Unsur Setiap Orang 
Menimbang bahwa untuk membuktikan suatu tindak pidana harus mengandung unsur perbuatan dan pertanggungjawaban kepada pelakunya sehingga harus dibuktikan unsur setiap orang, dalam hal ini untuk menunjuk subyek pelaku yang didakwa melakukan tindak pidana dimaksud, serta untuk menghindari kekeliruan terhadap orang. menimbang bahwa untuk membuktikan unsur setiap orang harus adanya kesesuaian antara identitas pelaku atau terdakwa tindak pidana yang berada di hadapan persidangan yang disesuaikan dengan identitas yang tercantum dalam surat dakwaan dan dalam hubungannya dengan perkara ini, yang dimaksud setiap orang adalah para terdakwa yang di akui oleh para terdakwa sendiri dan dibenarkan oleh para saksi, sehingga dengan demikian menurut pendapat Majelis Hakim unsur setiap orang tersebut telah terpenuhi.

b. Unsur Penyalahguna narkotika golongan I Menimbang bahwa berdasarkan fakta-fakta hukum yang ditemukan di persidangan bahwa para terdakwa terbukti sah dan meyakinkan telah melakukan tindak pidana penyalahgunaan narkotika jenis shabu-shabu untuk dirinya sendiri dan tidak sesuai peruntukan sebagaimana Pasal 7 dan 8 ayat (1) Undang-Undang Nomor 35 Tahun 2009 tentang Narkotika, dan terdakwa sendiri tidak memiliki izin serta bukan sebagai orang/ pejabat yang diebri wewenag untuk melakukan suatu perbuatan yang berkenaan dengan narkotika sebagaimana dimaksud oleh Undang-Undang Nomor 35 Tahun 2009 tentang narkotika. menimbang bahwa berdasarkan pertimbangan hukum diatas unsur Penyalahgun Narkotika golongan I telah etrpenuhi dari perbuatan para terdakwa.

6. Mempertimbangkan Tuntutan Jaksa Penuntut Umum

Menimbang bahwa Penuntut Umum telah menuntut agar Majelis Hakim menetapkan para terdakwa dilakukan rehabilitasi terhadap ketergantungan narkotika dan obat-obatan terlarang dan ditempatkan pada Balai pengobatan/ klinik BNN khusus rehabilitasi pecandu narkotika Provinsi Lampung di Kalianda selama 3(tiga) bulan.

Menimbang bahwa berdasarkn fakta-fakta yang ditemukan di persidangan Majelis Hakim sependapat dengan tuntutan Penuntut Umum tersebut dengan pertimbangan sebagai berikut:

a. bahwa berdasarkan surat keputusan Kepala BNN Provinsi Lampung Nomor KEP/42/I/Ka/Rh.00/2017 /BNNP-LPG Tanggal 3 Januari 2017 Tentang Penetapan Tim Assessment terpadu tingkat Provinsi
Lampung Tahun 2017 dan berdasarkan berita acara rapat pembahasan Kasus Nomor BA/03/II/TAT/2017/BNNP Tanggal 08 Februari 2017, para terdakwa adalah pengguna dan dapat dilakukan pengobatan/rehabilitasi.

b. bahwa para terdakwa termasuk dalam kategori pemakai atau pengguna yang merupakan korban dan bukan merupakan sebagai pengedar maupun produsen narkotika.

c. bahwa narkotika yang ditemukan dalam penguasaan para terdakwa adalah jenis shabu-shabu sebanyak 0,005 (nol koma nol nol lima) gram yang akan dipergunakan atau dikonsumsi terdakwa sendiri.

d. bahwa terdakwa bukanlah target operasi (TO) Polres Lampung Utara

e. bahwa berdasarkan ketentuan Pasal 127 ayat (3) jo Pasal 54 Undang-Undang Nomor 35 Tahun 2009 tentang Narkotika bahwa apabila terdakwa terbukti sebagai korban penyalahgunaan narkotika maka penyalahguna narkotika tersebut wajib menjalani rehabilitasi medis dan rehabilitasi sosial.

f. bahwa berdasarkan SEMA Nomor 4 Tahun 2010 jo SEMA Nomor 3 Tahun 2011 tentang penempatan koeban penyalahgunaan narkotika di dalam lembaga rehabilitasi medis dan rehabilitasi sosial dan berdasarkan Peraturan Pemerintah Nomor 25 Tahun 2011 tentang pelaksanaan wajib lapor pecandu narkotika, Majelis Hakim berpendapat bahwa para terdakwa adalah korban (mutual victimilation) yang sedang sakit dan harus di tolong sehingga walaupun para terdakwa terbukti bersalah, namun pidana yang lebih tepat adalah dalam bentuk rehabilitasi medis dengan tujuan untuk menyembuhkan atau memulihkan gangguan kejiwaan atau kondisi kesehatan para terdakwa sehingga para terdakwa tidak lagi mengkonsumsi narkotika.

g. Bahwa in casu Majelis Hakim berpendapat para terdakwa adalah seorang pecandu dimana sisis kesehatan merupakan orang yang sakit yang membutuhkan terapi kesehatan, sehingga tidaklah tepat penjara sebagai tempat penyelesaian masalah, karena penjara bukanlah tempat yang tepat untuk pecandu narkotika yang megalami ketergantungan. terlebih akhir-akhir ini kerawanan dan kerusuhan yang terjadi di rutan atau lapas dikarenakan sangat berlebihnya jumlah narapidana dari kapasitas yanga ada dan sebagian besar dari narapidana tersebut adalah narapidana narkotika yang berkualifikasi sebagai pengguna/ pemakai. 
Berdasarkan uraian fakta persidangan tersebut di atas maka Majelis Hakim memutuskan berdasarkan Pasal 54, Pasal 103 ayat (1) huruf a dan ayat (2), Pasal 127 ayat (1) huruf a dan ayat (3) Undang-Undang Nomor 35 Tahun 2009 tentang Narkotika, Peraturan pemerintah Nomor 25 Tahun 2011 dan Undang-Undang Nomor 8 Tahun 1981 tentang KUHAP serta perundangundangan yang bersangkutan maka Majelis Hakim dalam amar putusannya memutuskan:

1. Menyatakan tpara terdakwa telah terbukti secra sah dan meyakinkan bersalah melakukan tindak pidana Penyalahgunaan Narkotika Golongan I bagi diri sendiri sebagaimana dakwaan alternatif kedua.

2. Menjatuhkan pidana kepada para terdakwa oleh karena itu dengan pidana penjara masing-masing selama 2 (dua) bulan

3. Menyatakan pidana tersebut dijalani terdakwa dalam bentuk rehabilitasi medis

4. Memerintahkan agar para terdakwa menjalani pengobatan dan perawatan melalui rehabilitasi medis di Balai Pengobatan/ Klinik BNN khusus rehabilitasi pecandu narkotika provinsi Lampung di Kalianda selama 2(dua) bulan

5. Menetapkan masa penagkapan dan penahanan yang telah dijalani oleh para terdakwa di kurangkan seluruhnya dari pidana yang dijatuhkan.

6. Menetapkan masa para terdakwa menjalani pengobatan dan perawatan melalui rehabilitasi medis diperhitungkan sebagai masa menjalani pidana.

Berdasarkan uraian analisis di atas maka dapat diketahui bahwa Pertanggungjawaban Pelaku Tindak Pidana Penyalahgunaan Narkotika pada Putusan Nomor 67/ Pid.Sus/2017/ PN. Kbu yang disesuaikan dengan amar putusan Majelis Hakim bahwa para pelaku terbukti secara sah dan meyakinkan melakukan tindak pidana penyalahgunaan narkotika golongan I untuk diri sendiri dan menjatuhkan pidana penjara masingmasing selama 2 (dua) bulan dan menyatakan pidana tersebut dijalani terdakwa dalam bentuk rehabilitasi medis serta memerintahkan agar para terdakwa menjalani pengobatan dan perawatan melalui rehabilitasi medis di Balai Pengobatan/ Klinik BNN khusus rehabilitasi pecandu narkotika provinsi Lampung di Kalianda selama 2(dua) bulan.

\footnotetext{
3. Upaya Yang Dilakukan Oleh Satuan Reserse Narkoba Kepolisan Resor Lampung Utara Dalam Menanggulangi Peredaran Gelap Narkoba Di Wilayah Lampung Utara
}

Menurut Iptu Hartadi bahwa upaya yang dilakukan oleh Satuan Reserse Narkoba Kepolisan Resor Lampung Utara dalam menanggulangi peredaran gelap narkoba di wilayah Lampung Utara yaitu dilakukan dengan beberapa cara yaitu:

\section{Upaya Non Penal}

Upaya Non Penal adalah tindakan pencegahan sebelum melakukan tindakan kejahatan atau pelanggaran. Dalam upaya Non Penal yang ditekankan adalah menghilangkan unsur kesempatan untuk melakukan kejahatan atau pelanggaran. Jadi dalam upaya Non Penal, pihak terkait menutup kesempatan terjadinya pelanggaran maupun kejahatan. Dengan kata lain, upaya penanggulangan kejahatan adalah upaya yang dilakukan untuk mengadakan suatu perubahan keadaan masyarakat yang bersifat pasif dan dilakukan secara sistematik, terencana dan terarah yang bertujuan untuk menciptakan suasana kondusif guna menekan terjadinya kejahatan dalam hal ini peredaran gelap narkotika di daerah hukum Polres Lampung Utara.

Adapun upaya non penal dilakukan dengan dua cara yaitu preemtif dan preventif yakni sebagai berikut:

a. Pre emtif

Tindakan Polri ini dilakukan dengan melihat akar masalah penyebab terjadinya penyalahgunaan narkoba dengan melalui pendekatan sosial, situasional dan kemasyarakatan untuk menghilangkan unsur potensi gangguan. Tindakan preemtif yang dilakukan Polri dalam menanggulangi penyalahgunaan narkoba yaitu

1) Melakukan pembinaan kepada masyarakat Kabupaten Lampung Utara dengan cara penyuluhan, sosialisasi dan audiensi tentang bahaya dan dampak dari penyalahgunaan narkoba baik di sekolahsekolah, kantor pemerintahan/swasta, kelompok masyarakat/balai desa dan sebagainya. Hal ini untuk antisipasi dan pencegahan dini melalui kegiatankegiatan edukatif dengan tujuan menghilangkan potensi penyalahgunaan narkoba (faktor peluang) dan pendorong terkontaminasinya seseorang menjadi pengguna.

2) Melakukan sosialisasi bahaya narkoba melalui media sosial, pamflet spanduk, poster, brosur dan baliho yang tujuannya adalah sebagai pesan untuk melawan penyalahgunaan narkoba.

3) Melakukan sinergitas dengan instansi pemerintahan terkait, lembaga swadaya 
masyarakat, perkumpulan, ormas dan lain-lain. untuk saling melakukan edukasi kepada masyarakat khususnya kalangan muda melalui kampanye anti penyalahgunaan narkoba. Dengan melakukan kegiatan Kampanye anti peyalahgunaan narkoba : Hal ini dilakukan dengan 2 (dua) cara yakni pemberian informasi satu arah dari pembicara tentang bahaya pemakaian narkoba dan tanpa tanya jawab. Biasanya hanya memberikan garis besar, dangkal, dan umum. Informasi disampaikan oleh tokoh masyarakat (ulama, pejabat Polri, seniman dan sebagainya). Penyuluhan seluk beluk narkoba : Berbeda dengan kampanye yang monolog, penyuluhan bersifat dialog dengan tanya jawab. Bentuk penyuluhan dapat berupa seminar, ceramah, dan lain-lain. Tujuannya adalah untuk mendalami pelbagai masalah tentang narkoba sehingg a masyarakat benar-benar tahu dan karenanya tidak tertarik untuk menyalahgunakan narkoba. Pada penyuluhan ada dialog atau tanya jawab tentang narkoba lebih mendalam. Materi disampaikan oleh tenaga profesional dokter, psikolog, polisi, ahli hukum, .sosiolog - sesuai dengan tema penyuluhan. Penyuluhan tentang narkoba ditinjau lebih mendalam dari masingmasingaspek sehingga lebih menarik daripada kampanye.

b. Preventif (Pencegahan)

Anggota-anggota Kepolisian diterjunkan langsung ke wilayah-wilayah yang mencurigakan dijadikan tempat penampungan, penyimpanan, dan peredaran narkotika. adapun kegiatannya meliputi:

1) Mengadakan razia biasanya dilakukan ditempat hiburan malam dan juga tempattempat yang informasinya didapatkan dari masyarakat.

2) Mengadakan patroli rutin khususnya pada jam-jam malam yang biasa digunakan oleh pelaku dalam menjalankan aksinya.

2. Cara Penal yaitu upaya penindakan atau Represif merupakan upaya terakhir dalam memberantas penyalahgunaan narkotika yaitu dengan cara melakukan penindakan terhadap orang yang diduga menggunakan, menyimpan, menjual narkotika berdasarkan UndangUndang Nomor 35 Tahun 2009 tentang Narkotika. Langkah represif inilah yang dilakukan Polisi untuk menjauhkan masyarakat dari ancaman faktual yang telah terjadi dengan memberikan tindakan tegas dan konsisten sehingga dapat membuat jera para pelaku penyalahgunaan dan peredaran gelap narkotika.

\section{E. Kesimpulan}

Berdasarkan hasil pembahasan dan penelitian terhadap permasalahan maka dapat disimpulkan sebagai berikut :

1. Proses rekomendasi rehabilitasi penyalahgunaan narkotika oleh Tim Assessment Terpadu untuk pecandu narkotika yang tertangkap tangan dilakukan dengan cara yaitu:

a. Menentukan pecandu narkotika tersebut murni/konsumen atau pecandu merangkap pengedar sesuai dengan bukti-bukti dari proses penyidikan.

b. Tim Asesmen Terpadu melakukan asesmen berdasarkan permohonan tertulis dari penyidik.

c. Penyidik mengajukan permohonan paling lama 1x24 jam setelah penangkapan, dengan tembusan kepada Kepala BNNP Provinsi sesuai dengan tempat kejadian perkara.

d. Tim Asesmen Terpadu melakukan asesmen maksimal 2x 24 jam, selanjutnya hasil asesmen dari tim dokter dan tim hukum disimpulkan paling lama 3 hari ketiga.

e. Hasil Asesmen dari masing-masing tim asesmen dibahas pada pertemuan pembahasan kasus (case conference) pada hari keempat untuk ditetapkan sebagai rekomendasi Tim Asesmen Terpadu.

f. Rekomendasi Tim Asesmen Terpadu berisi keterangan mengenai peran tersangka dan/atau terdakwa dalam tindak pidana, tingkat ketergantungan penyalahguna narkotika, rekomendasi kelanjutan proses hukumnya dan tempat serta lama waktu rehabilitasi.

g. Rekomendasi Tim Assesmen terpadu di ditandatangani oleh ketua Tim Asesmen Terpadu.

2. Pertanggungjawaban Pelaku Tindak Pidana Penyalahgunaan Narkotika pada Putusan Nomor 67/ Pid.Sus/2017/ PN. Kbu yaitu pidana penjara masing-masing selama 2 (dua) bulan dan menyatakan pidana tersebut dijalani terdakwa dalam bentuk rehabilitasi medis serta memerintahkan agar para 
terdakwa menjalani pengobatan dan perawatan melalui rehabilitasi medis di Balai Pengobatan/ Klinik BNN khusus rehabilitasi pecandu narkotika provinsi Lampung di Kalianda selama 2(dua) bulan.

3. Upaya yang dilakukan oleh Satuan Reserse Narkoba Kepolisan Resor Lampung Utara dalam menanggulangi peredaran gelap narkoba di Wilayah Lampung Utara dilakukan dengan dua cara yakni : Upaya Non Penal terdiri dari upaya preemtif diantaranya Melakukan pembinaan kepada masyarakat Kabupaten Lampung Utara dengan cara penyuluhan, sosialisasi dan audiensi tentang bahaya dan dampak dari penyalahgunaan narkoba baik di sekolahsekolah, kantor pemerintahan/swasta, kelompok masyarakat/balai desa dan sebagainya. Melakukan sosialisasi bahaya narkoba melalui media sosial, pamflet spanduk, poster, brosur dan baliho yang tujuannya adalah sebagai pesan untuk melawan penyalahgunaan narkoba. Melakukan sinergitas dengan instansi pemerintahan terkait, lembaga swadaya masyarakat, perkumpulan, ormas dan lainlain untuk saling melakukan edukasi kepada masyarakat khususnya kalangan muda melalui kampanye anti penyalahgunaan narkoba.dan upaya preventif yaitu mengadakan razia biasanya dilakukan ditempat hiburan malam dan juga tempattempat yang informasinya didapatkan dari masyarakat. Mengadakan patroli rutin khususnya pada jam-jam malam yang biasa digunakan oleh pelaku dalam menjalankan aksinya. Kemudian Cara Penal (represif) yaitu melakukan penindakan terhadap orang yang diduga menggunakan, menyimpan, menjual narkotika berdasarkan UndangUndang Nomor 35 Tahun 2009 tentang Narkotika. Langkah represif inilah yang dilakukan Polisi untuk menjauhkan masyarakat dari ancaman faktual yang telah terjadi dengan memberikan tindakan tegas dan konsisten sehingga dapat membuat jera para pelaku penyalahgunaan dan peredaran gelap narkotika.

\section{F. Saran}

1. Hendaknya penegak hukum dalam memberikan rekomendasi rehabilitasi medis kepada para pelaku penyalahguna narkotika agar lebih hati-hati dan selektif agar pelaksanaannya dapat berjalan sesuai yang diharapkan.
2. Perlunya peningkatan peran serta masyarakat Kabupaten Lampung Utara untuk mendukung upaya penanggulangan dan pemberantasan peredaran gelap narkoba yang di lakukan oleh Polres Lampung Utara sehingga peredaran dan penyalahgunaan narkoba di wilayah Lampung Utara dapat diatasi dengan maksimal.

3. Bagi Pemerintah maupun orang tua sebaiknya lebih menambah edukasi, sosialisasi serta pengawasan tentang bahayanya narkotika kepada masyarakat khususnya kaum muda/ anak-anak sehingga upaya pencegahan dapat terlaksanakan dengan baik.

\section{DAFTAR PUSTAKA}

\section{A. BUKU-BUKU}

Abdulkadir Muhammad, Hukum dan Penelitian Hukum, PT. Citra Aditya Bakti, Bandung, 2004

Ahmad Rifai. Penemuan hukum. Sinar grafika. Jakarta. 2010

Adami Chazawi, Pelajaran Hukum Pidana, Raja Grafindo, Malang. 2002

Andi Hamzah, Hukum Acara Pidana Indonesia, Sinar Grafika, Jakarta, Edisi Revisi, 2004

AW Widjaja, Masalah Kenakalan Remaja Dan Penyalahgunaan Narkotika, Bandung, Armico, 1985

Barda Nawawi Arief, Bunga Rampai Kebijakan Hukum Pidana, Kencana, Semarang, 2008

- Masalah Penegakan Hukum dan Kebijakan Penanggulangan Kejahatan. Citra Aditya Bakti, Bandung, 2001

Bambang Purnomo, Asas-asas Hukum Pidana, Ghalia Indonesia, Jakarta, 1985

Buku Advokasi Pencegahan Penyalahgunaan Narkoba Bagi Petugas Lapas Dan Rutan, Pemahaman Tentang Bahaya Penyalahgunaan Narkoba, BNN, Jakarta, 2013 
D. Soedjono, Segi Hukum Tentang Narkotika di Indonesia. Karya Nusantara, Bandung, 2000

Dharana Lastarya. Narkoba, Perlukah Mengenalnya. Pakarkarya. Jakarta 2006

Djoko Prakoso, dkk., Kejahatan-Kejahatan yang Merugikan dan Membahayakan Negara, Bina Aksara, Jakarta, 2009

Gatot Supramono, Hukum Narkotika Indonesia. Djambatan, Jakarta. 2001

Hari Sasangka, Narkotika dan Psikotropika Dalam Hukum Pidana, Mandar Maju, Bandung, 2003

Lamintang dan Samosir, Hukum Pidana Indonesia, Sinar Baru, Bandung, 1983

Laurence M. Friedmann, Teori dan Filsafat Hukum : Idealisms Filosofis dan Problema Keadilan (Susunan 11), PT, Raja Grafindo Persada, Jakarta, 1994

Lilik Mulyadi, Kapita Selekta Hukum Pidana Kriminologi dan Victimologi, Djambatan, Jakarta, 2007

Lydia Harlina Martono, Satya Joewana, Menangkal Narkoba dan Kekerasan, Jakarta,Balai Pustaka, 2008

Moeljatno, Asas-Asas Hukum Pidana, Rineka Cipta, Jakarta, 2003

Moh. Taufik Makarao, dkk., Tindak Pidana Narkotika, Ghalia Indonesia, Jakarta, 2003

Muladi. Hak Asasi Manusia, Politik dan Sistem Peradilan Pidana. Badan Penerbit UNDIP. Semarang. 2001

Ninik Widiyanti, Perkembangan Kejahatan dan Masalahnya Ditinjau dari Segi Kriminolog dan Sosial, PT. Pradnya Paramita, Jakarta, 1987

P.A.F. Lamintang, Dasar-Dasar Hukum Pidana Indonesia, PT. Citra Aditya Bakti, Bandung,1997, hlm.284

Pipin Syarifin, Hukum Pidana Di Indonesia, CV. Pustaka Setia, Bandung, 2000
Peter Mahmud Marzuki, Penelilian Hukum, Prenada Media Group, Jakarta, 2005

R. Tresna, Asas-Asas Hukum Pidana, Pustaka Tinta Mas, Surabaya, 1994

Roeslan Saleh, Perbuatan Pidana dan Pertanggun jawaban Dalam Hukum Pidana, Aksara Baru, Jakarta,2002

Sidharta Arief, Meuwissen Tentang Pengembanan Hukum, Ilmu Hukum, Teori Hukum dan Filsafat Hukum, PT Refika Aditama, Bandung, 2007

Soerjono Soekanto, Penanggulangan Kejahatan, Rajawali Pers, Jakarta, 1984

Pengantar Penelitian Hukum, UI-Press, Jakarta, 1986

\section{B. UNDANG-UNDANG DAN PERATURAN LAINNYA}

Undang-Undang Dasar 1945 dan Hasil Amandemen.

Undang-Undang Nomor 1 Tahun 1946 tentang Pemberlakuan Kitab Undang-Undang Hukum Pidana (KUHP).

Undang-Undang Nomor 8 Tahun 1981 tentang Hukum Acara Pidana (KUHAP).

Undang-Undang Nomor 2 Tahun 2002 tentang Kepolisian Negara Republik Indonesia.

Undang-Undang Nomor 4 Tahun 2004 jo UndangUndang Nomor 48 Tahun 2009 tentang Kekuasaan Kehakiman Republik Indonesia.

Undang-Undang Nomor 16 Tahun 2004 tentang Kejaksaan Republik Indonesia.

Undang-Undang Nomor 35 Tahun 2009 tentang Narkotika.

Peraturan Pemerintah Nomor 27 Tahun 1983 tentang Pedoman Pelaksanaan Kitab Undang-Undang Hukum Acara Pidana (KUHAP).

Peraturan Pemerintah RI Nomor 58 Tahun 2010 Tentang Perubahan Atas PP RI Nomor 27 Tahun 1983 Tentang Pedoman Pelaksanaan Kitab Undang-Undang Hukum Acara Pidana. 
Peraturan Pemerintah RI Nomor 92 Tahun 2015 tentang Perubahan Pelaksanaan Kitab Undang-Undang Hukum Acara Pidana (KUHAP).

Peraturan Kepala Badan Narkotika Nasional Nomor 11 Tahun 2014 tentang Tata Cara Penanganan Tersangka dan/atau Terdakwa Pecandu Narkotika dan Korban Penyalahgunaan Narkotika ke Dalam Lembaga Rehabilitasi

\section{SUMBER LAINNYA}

J.C.T. Simorangkir, Rudi T. Erwin dan J.T. Prasetyo, Kamus Hukum, Edisi Kesepuluh, Sinar Grafika, Jakarta, 2006

Pusat Bahasa Departemen Pendidikan Nasional, Kamus Besar Bahasa Indonesia, Balai Pustaka, Jakarta, 2001

Redaksi Badan Penerbit Alda Jakarta, Menanggulangi Bahaya Narkotika, (Amanah R.I/B.P. Alda) 